Check for updates

Cite this: RSC Adv., 2019, 9, 32097

\title{
Biological characterization of surface-treated dental implant materials in contact with mammalian host and bacterial cells: titanium versus zirconia†
}

\begin{abstract}
Danyal A. Siddiqui, (D a Joel J. Jacob, ${ }^{b}$ Alikhan B. Fidai ${ }^{a}$ and Danieli C. Rodrigues*a
Commercially pure titanium (cpTi) remains the material of choice for dental implants due to its surface properties which promote osseointegration. Recently, zirconia $\left(\mathrm{ZrO}_{2}\right)$ has been used as an alternative material due to its immunity to corrosion, mechanical strength, and biocompatibility. Previous in vitro studies evaluating oral bacterial attachment and mammalian host cell response to cpTi and $\mathrm{ZrO}_{2}$ have yielded mixed results. Thus, the aim of the present study was to systematically evaluate the growth of early-colonizing oral bacteria and mammalian host cells on cpTi and $\mathrm{ZrO}_{2}$ after three clinically-relevant surface treatments: polishing, acid-etching, or sandblasting. Polishing produced smooth surfaces (Sa: 0.08-0.22 $\mu \mathrm{m}$ ) while acid-etching (Sa: 0.75-1.20 $\mu \mathrm{m}$ ) and sandblasting (Sa: 0.87-1.00 $\mu \mathrm{m}$ ) yielded rough variants. All surfaces were relatively hydrophilic $\left(\theta_{c} \leq 31^{\circ}\right)$. Overall, the adherent bacterial count did not significantly differ between $\mathrm{cpTi}$ and $\mathrm{ZrO}_{2}$ after 1 or 3 days for all Streptococcus strains $(p>0.05)$. Bacterial count was only greater on rough versus smooth variants for $S$. sanguinis and S. salivarius. Acidetched $\mathrm{cpTi}$ induced the highest proliferation of macrophages and fibroblasts but the lowest for preosteoblasts after 1 and 3 days. All surfaces exhibited comparable fibroblast and pre-osteoblast proliferation by 7 days. Pre-osteoblast differentiation continually increased between 7 and 14 days and was higher on rougher surfaces. No differences in mammalian cellular attachment on $\mathrm{cpTi}$ and $\mathrm{ZrO}_{2}$ were observed. Within the study's limitations, early-colonizing oral bacterial adhesion and mammalian cell growth is similar on both smooth and rough cpTi and $\mathrm{ZrO}_{2}$.
\end{abstract}

Received 2nd August 2019 Accepted 29th September 2019 DOI: $10.1039 / c 9 r a 06010 c$ rsc.li/rsc-advances

\section{Introduction}

Dental implant placement is one of the fastest growing procedures in dentistry with nearly 800000 being implanted annually in the US and 1.8 million in the European Union. ${ }^{1}$ Dental implants are devices that serve to restore natural tooth function with success being determined by establishment of osseointegration. ${ }^{2}$ Osseointegration is the process by which a structural and functional interface is developed between the implant and surrounding bone tissue. ${ }^{3}$ Commercially pure titanium (cpTi) has been the material of choice in dental implants due to the spontaneous formation of a passive oxide layer $\left(\mathrm{TiO}_{2}\right)$, which provides biocompatibility, corrosion resistance, and osseointegrative properties in addition to being conducive to various surface treatments. ${ }^{4-9}$ Also, cpTi possesses mechanical strength which allows it to withstand loading encountered in the oral cavity. ${ }^{7}$ However, cpTi can undergo

${ }^{a}$ Department of Bioengineering, The University of Texas at Dallas, $800 \mathrm{~W}$. Campbell Road, Richardson, TX, USA 75080.E-mail:danieli@utdallas.edu

${ }^{b}$ Department of Biological Sciences, The University of Texas at Dallas, $800 \mathrm{~W}$. Campbell Road, Richardson, TX, USA 75080

$\dagger$ Electronic supplementary information (ESI) available. See DOI: 10.1039/c9ra06010c corrosion under conditions experienced in the oral cavity, which can damage its surface and disrupt osseointegration. ${ }^{10}$ Specifically, oral environmental factors can result in cpTi dental implant failure through mechanisms such as chronic inflammation leading to bone loss due to peri-implantitis or corrosion-assisted mechanical fatigue leading to implant fracture. ${ }^{11-13}$ Furthermore, oral bacterial adhesion can occur synergistically with mechanical loading and exacerbate corrosion-mediated processes until implant failure. ${ }^{13-15}$ Ultimately, these factors have contributed to the current failure rate of $2.3-9.1 \%$ for cpTi dental implants 15 years postimplantation. ${ }^{16-18}$

Zirconia $\left(\mathrm{ZrO}_{2}\right)$ is a ceramic that has recently been applied as the sole material comprising the dental implant body or screw. $\mathrm{ZrO}_{2}$ is a favorable biomaterial due to being composed entirely of an inert oxide, imparting biocompatibility, corrosion resistance, and aesthetic appeal. ${ }^{19-22}$ The most popular form of $\mathrm{ZrO}_{2}$ used in implantable devices is its tetragonal phase achieved through partial stabilization with yttrium oxide $\left(\mathrm{Y}-\mathrm{ZrO}_{2}\right)$ although other metal oxides including magnesium oxide $(\mathrm{Mg}-$ $\mathrm{ZrO}_{2}$ ) have been used as an stabilizer to improve mechanical strength and aging behavior. ${ }^{23}$ In particular, $\mathrm{Y}-\mathrm{ZrO}_{2}$ can undergo a tetragonal-to-monoclinic phase transformation, 
which reduces susceptibility to fracture through a phenomenon known as transformation toughening, promoting self-repair of microcracks and thereby increasing fatigue performance. ${ }^{24,25}$ Despite the potential advantages of using $\mathrm{ZrO}_{2}$ over cpTi, cumulative failure rates of $1.8-28.7 \%$ for $\mathrm{ZrO}_{2}$-based dental implant systems after 12 months have been reported, indicating that $\mathrm{ZrO}_{2}$ may still be susceptible to the same oral environmental factors as $\mathrm{cpTi}^{26}$

Among oral environmental factors, bacterial biofilm has been considered a main etiological agent of dental implant failure through prevention of osseointegration (early stage) or triggering its loss (late stage). ${ }^{27}$ Within the first few hours of implantation, proteins collect on the implant surface, forming a pellicle that provides an ideal site for cell attachment. ${ }^{28}$ This ultimately leads to competition between mammalian host cells and oral bacteria to colonize the implant surface. If earlycolonizing bacteria win, a bacterial biofilm develops around the implant, which can prevent mammalian cell adhesion and ultimately inhibit osseointegration. Furthermore, byproducts of bacterial metabolism released from a growing biofilm like lactic acid can decrease the $\mathrm{pH}$ around the underlying substrate, creating a localized acidic environment that can further damage the surrounding host tissue and dental implant surface. ${ }^{29}$ For cpTi, corrosion may be accelerated, resulting in dissolution of metal particles which can trigger an enhanced inflammatory response..$^{30}$ On the other hand, if mammalian cells colonize the surface, normal wound healing can proceed with soft tissue seal formation around the implant collar and osseointegration with the implant screw. However, if the soft tissue seal is penetrated, bacteria may colonize the implant surface, disrupting established osseointegration and triggering a chronic inflammatory response which can eventually lead to implant failure. ${ }^{\mathbf{1 2}}$

Because bacterial adhesion and biofilm formation play a key role in both early and late stage implant complications, it is crucial to develop ways to mitigate their attachment on dental implant surfaces. In particular, reducing the adhesion of early colonizers like Streptococcus species can hinder the development of a mature biofilm that can provide a suitable environment for pathogenic, late-colonizing bacterial strains such as Porphyromonas gingivalis to grow. ${ }^{31}$ One potential strategy is employing $\mathrm{ZrO}_{2}$ dental implants for which some studies have reported significantly lower plaque and biofilm growth as compared to cpTi. ${ }^{32-35}$ In contrast, other studies have observed no improvement or even greater bacterial growth on $\mathrm{ZrO}_{2} \cdot{ }^{36,37}$ In addition to substrate material, surface modifications applied to an implant material may influence both bacterial adhesion and mammalian cellular response within the oral cavity. Three major surface modifications currently applied are polishing, acid-etching, and sandblasting, each of which impart distinct surface features and roughness. Polished surfaces are relatively smooth while acid-etched and sandblasted surfaces can yield micro- and macro-rough surfaces, respectively. ${ }^{38}$ In terms of oral bacterial attachment, the effect of surface roughness on earlycolonizing bacterial adhesion remains inconclusive. ${ }^{36,39-41}$

Regardless of when bacterial colonization occurs postimplant placement, the lack or loss of suitable mammalian host cell interface with the implant surface can lead to failure.
Upon implantation, macrophages are initially recruited at the surgical site. ${ }^{42}$ Pro-inflammatory (M1) macrophages produce an acute inflammatory response while anti-inflammatory (M2) macrophages assist in resolving this initial inflammation to subsequently enter the healing phase. ${ }^{\mathbf{4 2}}$ This inflammatory response is a vital component of the healing process, and its quick resolution is necessary for osseointegration of the implant. In the next phase of the healing process, fibroblasts begin to proliferate at the surgical site, aiding in the formation of necessary soft connective tissue around the implant by secreting extracellular matrix and collagen. ${ }^{43}$ As soft tissue is established around the implant, osteoblasts proliferate around the base of the implant to form bone tissue. ${ }^{44}$ Overtime, osteoblasts mature and secrete minerals necessary to form hydroxyapatite crystals. ${ }^{44}$ The deposition of these hydroxyapatite crystals strengthens the connection between bone tissue and the implant surface and is responsible for osseointegration.

In the literature, limited results have been reported for proliferation of macrophages, fibroblasts, and osteoblasts on surface-modified cpTi and $\mathrm{ZrO}_{2}$. Moreover, the outcome of mammalian host cell response to $\mathrm{ZrO}_{2}$ versus cpTi surfaces in vitro has yielded mixed results. ${ }^{36,45-48}$ Specifically, some studies have reported greater fibroblast and osteoblast proliferation on $\mathrm{ZrO}_{2}$ surfaces as compared to cpTi. ${ }^{\mathbf{4 7}, 48}$ In contrast, other studies have demonstrated no significant difference in macrophage, fibroblast, or osteoblast growth on $\mathrm{ZrO}_{2}$ and cpTi surfaces. ${ }^{45,46,49}$ Likewise, differences in mammalian cellular growth on smooth surfaces (polished) as opposed to rougher ones (sandblasted and/or acid-etched) have been debated in the literature. ${ }^{50-52}$ In particular, greater osteoblast proliferation has been observed on rougher cpTi and $\mathrm{ZrO}_{2}$ surfaces as opposed to their smoother counterparts. ${ }^{\mathbf{5 0 , 5 1}}$ On the other hand, fibroblasts and preosteoblasts have been shown to grow equally well on $\mathrm{ZrO}_{2}$ and cpTi substrates in vitro. ${ }^{52-55}$

Based on the findings of these previous studies, the trends in terms of oral bacterial adhesion and mammalian cellular proliferation on various surface-modified cpTi and $\mathrm{ZrO}_{2}$ appear to be inconclusive. Therefore, a comprehensive study is needed to assess the effect of various substrate-surface modification combinations on the proliferation of both early-colonizing bacteria and mammalian host cells involved in wound healing and osseointegration post-implantation. Thus, the aim of the present study was to systematically evaluate early-colonizing bacterial adhesion and mammalian cell growth on clinicallyrelevant, surface-modified cpTi and $\mathrm{ZrO}_{2}$. It was hypothesized that $\mathrm{ZrO}_{2}$ surfaces would exhibit fewer adherent bacteria and greater mammalian cell growth than cpTi.

\section{Methodology}

\subsection{Materials}

In this study, nine groups of various dental implant biomaterials and surface treatment combinations were studied. All specimens were sectioned into disks $(\varnothing \sim 5 \mathrm{~mm} \times 3 \mathrm{~mm})$ using a precision saw (PICO 155P, Pace Technologies, Tucson, AZ). Three substrates were investigated: (i) commercially pure titanium (cpTi, McMaster-Carr, Elmhurst, IL), (ii) 3\% mol partially 
yttria-stabilized zirconia $\left(\mathrm{Y}-\mathrm{ZrO}_{2}\right.$, Ortech Advanced Ceramics, Sacramento, CA), and (iii) 3\% mol partially magnesia-stabilized zirconia $\left(\mathrm{Mg}-\mathrm{ZrO}_{2}, \mathrm{McMaster}-\mathrm{Carr}\right.$, Elmhurst, IL). Each substrate underwent one of three different surface treatments: (a) polishing (-P) until mirror-like surface finish using an automated polisher (NANO 1000T and FEMTO 1100, Pace Technologies, Tucson, AZ), (b) acid-etching (-A) for $1 \mathrm{~h}$ in $34 \%$ sulfuric acid $\left(\mathrm{H}_{2} \mathrm{SO}_{4}\right)$ and $14 \%$ hydrochloric acid $(\mathrm{HCl})$ for cpTi and $40 \%$ hydrofluoric acid (HF) for both $\mathrm{Y}-\mathrm{ZrO}_{2}$ and $\mathrm{Mg}-\mathrm{ZrO}_{2}$, or (c) sandblasting (-S) with $50 \mu \mathrm{m}$ alumina $\left(\mathrm{Al}_{2} \mathrm{O}_{3}\right)$ particles at 70 psi and $\sim 1 \mathrm{~mm}$ working distance. Post-surface treatment, all specimens were sequentially sonicated for $15 \mathrm{~min}$ in acetone, deionized water, and ethanol. Afterward, the specimens were dried in an oven at $60{ }^{\circ} \mathrm{C}$ for $24 \mathrm{~h}$ before further testing.

\subsection{Scanning electron microscopy}

Scanning electron microscopy (SEM) was performed on each specimen type post-surface treatment to observe qualitative changes in surface morphology. SEM images were obtained using a ZEISS EVO LS 15 SEM (Oberkochen, Germany) under variable pressure mode $(40 \mathrm{~Pa})$ at $1000 \times$ magnification and 15 $\mathrm{kV}$ accelerating voltage.

\subsection{Surface roughness}

To quantitatively assess the surface roughness of all specimens after surface treatment, the arithmetic mean height (Sa) and increase in surface area due to the surface texture as compared to a flat surface, known as the developed interfacial area ratio $(\mathrm{Sdr})$, were measured $(n=3)$. Three randomly chosen areas $(0.62 \mu \mathrm{m} \times 0.47 \mu \mathrm{m})$ per specimen were scanned at $10 \times$ magnification using an optical profilometer (Contour GT, Bruker, Billerica, MA).

\subsection{Contact angle measurements}

The wettability of all specimens after surface treatment was determined by measuring the contact angle $\left(\theta_{\mathrm{c}}\right)$ using an optical microscope (VHX-2000, Keyence, Itasca, IL) positioned at $90^{\circ}$ relative to the normal of the surface. Two $\mu$ l of deionized water was placed at the center of each specimen, and the angles formed at both the right and left sides of the substrate-water and water-air interfaces were recorded and used to calculate an average contact angle $(n=6)$. To better evaluate the surface hydrophilicity of specimens prior to seeding with mammalian cells, contact angle measurements were repeated after wetting the surface with $10 \mathrm{ul}$ of Dulbecco's modified Eagle's media (Gibco, Thermo Fisher Scientific, Waltham, MA) for $15 \mathrm{~min}$ before aspirating the media and placing the $2 \mu$ drop of deionized water $(n=6)$.

\subsection{Immersion in early-colonizing bacteria}

In this study, three early-colonizing oral bacterial strains were investigated: Streptococcus mutans (ATCC 700610, Manassas, VA), Streptococcus sanguinis (ATCC 10556, Manassas, VA), and Streptococcus salivarius (ATCC 13419, Manassas, VA). Bacteria were struck from a frozen stock at $-80{ }^{\circ} \mathrm{C}$ onto Brain and Heart
Infusion (BHI, Becton Dickinson, Franklin Lakes, NJ) agar plates and incubated for $48 \mathrm{~h}$. All incubation was maintained at $37^{\circ} \mathrm{C}$ and $5 \% \mathrm{CO}_{2}$ for the duration of the experiment. Afterward, single colonies of each strain were inoculated in $5 \mathrm{~mL}$ of $\mathrm{BHI}$ broth and incubated for $24 \mathrm{~h}$. Overnight culture for each bacterial strain was then diluted to an optical density reading of 0.01 at $600 \mathrm{~nm}$ wavelength using a spectrophotometer (Genesys 30, Thermo Fisher Scientific, Waltham, MA). Specimens of each biomaterial and surface treatment combination $(n=3)$ were then immersed in $500 \mu \mathrm{l}$ of diluted bacterial media for 24 or $72 \mathrm{~h}$ in either a monoculture of each strain or a polyculture of all three strains. Half of the immersion media $(250 \mu \mathrm{l})$ was replaced every $24 \mathrm{~h}$ with fresh BHI broth to replenish nutrients and maintain bacterial cell viability. All experiments were performed in triplicates.

\subsection{Quantifying adherent bacteria}

Once the duration of the immersion had elapsed, adherent bacterial count was quantified. Adherent bacteria were defined as those which remained on the specimen after being washed three times in $1 \times$ phosphate-buffered saline (PBS) but detached after $5 \mathrm{~min}$ of ultrasonication in PBS. Aliquots of adherent bacteria were plated on BHI agar plates after performing five 10fold serial dilutions. These plates were then incubated for $24 \mathrm{~h}$, and the individual colony forming units (CFU) were counted to obtain the logarithm of CFU per ml.

\subsection{Mammalian cell seeding}

Three mammalian cell lines were used in the present study: primary human macrophages, human gingival fibroblasts (HGF-1), and murine pre-osteoblasts (MC3T3-E1). Human macrophages (Celprogen, Torrance, CA) and fibroblasts (Lifeline Cell Technology, Frederick, MD) were cultured in Dulbecco's modified Eagle's media (Gibco, Thermo Fisher Scientific, Waltham, MA), while pre-osteoblasts (MC3T3-E1 Subclone 4, ATCC CRL-2593, Manassas, VA) were cultured in Minimal Essential Medium (MEM) Alpha Modification (Hyclone, Logan, UT). All media were supplemented with $10 \%$ fetal bovine serum (Hyclone, Logan, UT) and 1\% penicillin-streptomycin (Gibco, Thermo Fisher Scientific, Waltham, MA). All cell culture was grown at $37{ }^{\circ} \mathrm{C}$ in $5 \% \mathrm{CO}_{2}$ throughout testing and were passaged in T-75 flasks until the recommended number of passages per the manufacturer was reached. Cells were directly seeded onto disks $(n=3)$ at a density of $2.5 \times 10^{4}$ cells per $\mathrm{cm}^{2}$ for macrophages and $3.125 \times 10^{4}$ cells per $\mathrm{cm}^{2}$ for fibroblasts and preosteoblasts and incubated for 1 to $2 \mathrm{~h}$. Post-incubation, the specimens were transferred into individual wells of a 96-well plate, and the wells containing the disks were washed with $1 \times$ PBS prior to adding $100 \mu \mathrm{L}$ of corresponding media. Wells containing only media served as negative controls while cells grown on tissue-culture treated polystyrene served as positive controls. Media was changed every $48 \mathrm{~h}$ as needed.

\subsection{Evaluation of mammalian cellular proliferation}

A colorimetric assay (ATCC 30-1010K) was used to evaluate cellular proliferation on the various specimens. After adding fresh media, 10 
$\mu \mathrm{L}$ of 3-[4,5-dimethylthiazol-2-yl]-2,5-diphenyltetrazolium bromide (MTT) reagent was added to each well. The plate was then incubated for $4 \mathrm{~h}$ in the dark at $37^{\circ} \mathrm{C}$. Next, $100 \mu \mathrm{L}$ of detergent was added to all wells and incubated overnight at $37{ }^{\circ} \mathrm{C}$ to solubilize the reduced product (formazan) produced by the cells on the disks. Finally, disks were removed from the wells, and absorbance measurements were taken at $570 \mathrm{~nm}$ using an automated plate reader (Synergy Mx, Biotech, Winooski, VT). The relative proliferation was calculated by subtracting the blank values (negative control) from absorbance measurements, dividing by the well or specimen surface area, and normalizing to the average value obtained for positive control. All values were then normalized to the average value obtained for cells grown on polished cpTi after 1 day for each cell line to allow for direct comparison across all time points.

\subsection{Evaluation of cellular differentiation of pre-osteoblasts}

An alkaline phosphatase (ALP) assay (Abcam, Cambridge, UK) was used to observe differentiation of pre-osteoblasts. Preosteoblasts were incubated with MEM Alpha Modification supplemented with $10 \mathrm{mM} \beta$-glycerophosphate and $50 \mu \mathrm{g} \mathrm{ml}$ of ascorbic acid to induce differentiation. Media was changed every $48 \mathrm{~h}$ as needed. After incubation for 7, 10, or 14 days, the ALP assay was performed. The cell culture wells were replenished with $50 \mu \mathrm{l}$ of media, and subsequently $30 \mu \mathrm{L}$ of ALP assay buffer and $50 \mu \mathrm{L}$ of $p$-nitrophenyl phosphate (pNPP) were added to each well. The plate was kept at $25^{\circ} \mathrm{C}$ for $1 \mathrm{~h}$ before adding 20 $\mu \mathrm{L}$ of stop solution. Disk specimens were then removed from the wells, and the absorbance values were measured at an optical density of $405 \mathrm{~nm}$ using an automated plate reader (Synergy Mx, Biotek, Winooski, VT). Based on previously derived calibration curves, the absorbance values were converted into units of ALP activity and normalized based on surface area and average positive control values.

\subsection{Confocal microscopy imaging}

Cellular attachment of macrophages, fibroblasts, and preosteoblasts on all surfaces was observed after 1, 3 and 7 days using fluorescent dyes with a confocal laser scanning microscope (FLUOVIEW FV3000, Olympus, Center Valley, PA). Cells were fixed with $4 \%$ paraformaldehyde for $30 \mathrm{~min}$ prior to staining the nuclei with $4^{\prime}$,6-diamidino-2-phenylindole (DAPI, Invitrogen, Carlsbad, CA) and F-actin with Alexa Fluor 488 dye (Invitrogen, Carlsbad, CA). All imaging was performed at $30 \times$ magnification.

\subsection{Statistical analysis}

The surface roughness parameters, contact angles, number of adherent bacteria, average relative proliferation values of mammalian cells, and differentiation values of pre-osteoblasts between groups were compared for statistical significance using two-way analysis of variance (ANOVA) followed by post hoc Tukey test (GraphPad Prism 7, San Diego, CA). For surface roughness and contact angle measurements, the grouping factors were the substrate material and surface treatment. For each bacterial strain or mammalian cell line, the grouping factors were the time points and substrate material-surface treatment combination. The significance threshold was set to 95\% $(\alpha=0.05)$.

\section{Results and discussion}

Zirconia $\left(\mathrm{ZrO}_{2}\right)$ has recently emerged as a promising alternative to commercially pure titanium (cpTi) comprising dental implant systems, including the implant body or screw. In spite of several clinical and animal studies showing comparable survival rates and osseointegration outcome for $\mathrm{ZrO}_{2}$ and cpTi surfaces, mixed results have been reported regarding mammalian cell growth and oral bacterial adhesion on $\mathrm{ZrO}_{2}$ surfaces in vitro. ${ }^{34,46,56,57}$ However, direct comparisons of these conflicting results from different studies in the literature cannot be made due to differences in experimental methodology, including specimen preparation, types of applied surface treatment, and quantities measured to assess the biological performance of $\mathrm{ZrO}_{2}$ versus Ti. In particular, a comprehensive assessment of the effect of both substrate material and surface treatment on bacterial and mammalian cellular behavior is crucial. That is, the morphology and features on a given surface act as cues influencing cellular response which in turn dictate the outcome for successful implantation. Thus, the purpose of this study was to systematically evaluate both early-colonizing bacterial adhesion and mammalian cell growth on three dental implant materials: cpTi and two different $\mathrm{ZrO}_{2}$ compositions, $\mathrm{Y}-\mathrm{ZrO}_{2}$ and $\mathrm{Mg}-\mathrm{ZrO}_{2}$. To investigate cellular response to individual surface treatments, each substrate underwent one of three clinically-relevant surface treatments: polishing, acid-etching, or sandblasting. Throughout the remainder of the text, all polished, acid-etched, and sandblasted substrate variants for cpTi, $\mathrm{Y}-\mathrm{ZrO}_{2}$, and $\mathrm{Mg}-\mathrm{ZrO}_{2}$ are labeled as -P, -A, and -S, respectively.

\subsection{Surface characterization}

In order to evaluate the morphology of all specimens after surface treatment (Fig. 1), scanning electron microscopy (SEM) was used. For cpTi-P, Y-ZrO $-\mathrm{P}$, and $\mathrm{Mg}-\mathrm{ZrO}_{2}-\mathrm{P}$ (Fig. $1 \mathrm{~A}$, D and $\mathrm{G})$, all surfaces demonstrated smooth, mirror-like finish with faint, superficial scratches characteristic after polishing. In addition, tiny, shallow, and narrow-diameter pits characteristic of chemical polishing were also observed on both $\mathrm{Y}-\mathrm{ZrO}_{2}-\mathrm{P}$ and $\mathrm{Mg}-\mathrm{ZrO}_{2}-\mathrm{P}$ (Fig. 1D and G). In contrast, cpTi-A exhibited a microrough, pitted surface with peaks and valleys distributed across the entire surface (Fig. 1B). Similar features were also present on $\mathrm{Y}-\mathrm{ZrO}_{2}$-A (Fig. 1E) and $\mathrm{Mg}-\mathrm{ZrO}_{2}-\mathrm{A}$ (Fig. $1 \mathrm{H}$ ) but with deeper pits and less uniform distribution of surface features. A qualitative increase in apparent surface roughness was clearly visible (Fig. 1C, F and I) but most prominent on cpTi-S (Fig. 1C) as compared to both $\mathrm{Y}-\mathrm{ZrO}_{2}-\mathrm{S}$ and $\mathrm{Mg}-\mathrm{ZrO}_{2}-\mathrm{S}$ (Fig. $1 \mathrm{~F}$ and I).

The mean arithmetic height $(\mathrm{Sa})$ and developed interfacial area ratio (Sdr) values for surface-treated cpTi, $\mathrm{Y}-\mathrm{ZrO}_{2}$, and $\mathrm{Mg}$ $\mathrm{ZrO}_{2}$ are shown in Table 1. All polished substrates had significantly lower Sa values as compared to their acid-etched or sandblasted counterparts for each substrate material $(p<0.05)$, but the Sa values of all polished surfaces were statistically similar to each other $(p>0.05)$. Similarly, all polished surfaces 


\section{Polished (-P) Acid-etched (-A) Sandblasted (-S)}

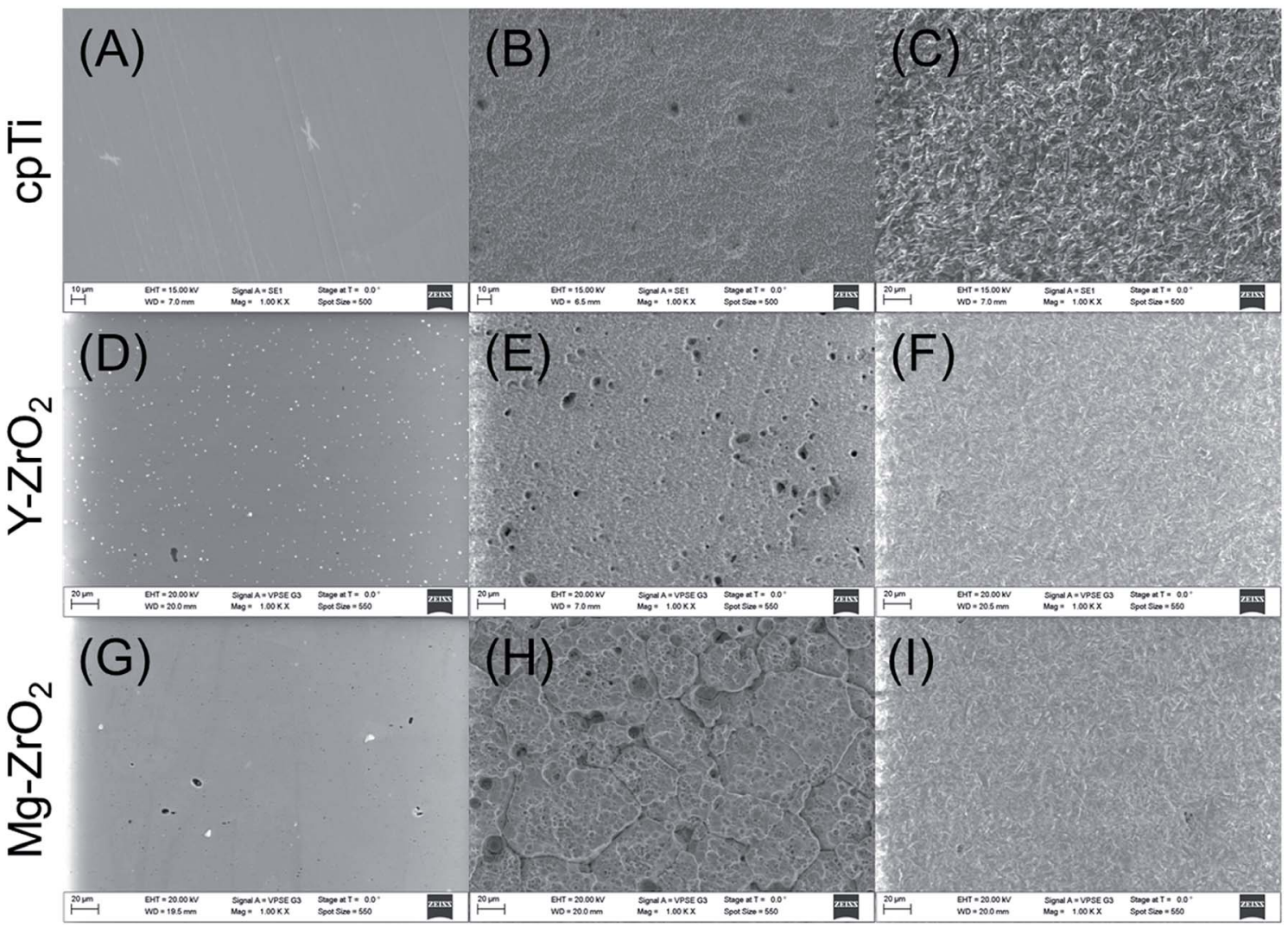

Fig. 1 Scanning electron microscopy images of (A, D and G) polished (-P), (B, E and H) acid-etched (-A), and (C, F and I) sandblasted (-S) cpTi, Y$\mathrm{ZrO}_{2}$, and $\mathrm{Mg}-\mathrm{ZrO}_{2}(1000 \times$ magnification).

had significantly lower Sdr values as compared to acid-etched and sandblasted variants $(p<0.05)$. CpTi-A had a lower average Sa value than cpTi-S while the opposite behavior was observed for both $\mathrm{Y}-\mathrm{ZrO}_{2}$ and $\mathrm{Mg}-\mathrm{ZrO}_{2}$ variants but was not statistically significant $(p<0.05)$. Correspondingly, cpTi-A had a lower average Sdr value than cpTi-S $(p>0.05)$ while $\mathrm{Y}_{-} \mathrm{ZrO}_{2}-\mathrm{S}$ and $\mathrm{Mg}-\mathrm{ZrO}_{2}-\mathrm{S}$ had significantly lower $\mathrm{Sdr}$ values than $\mathrm{Y}-\mathrm{ZrO}_{2}-\mathrm{A}$ and $\mathrm{Mg}-\mathrm{ZrO}_{2}-\mathrm{A}(p<0.05)$. Among acid-etched surfaces, $\mathrm{Mg}-$ $\mathrm{ZrO}_{2}$-A had significantly higher Sa values than cpTi-A and Y$\mathrm{ZrO}_{2}-\mathrm{A}(p<0.05)$. Likewise, $\mathrm{Mg}-\mathrm{ZrO}_{2}-\mathrm{A}$ had the highest Sdr value followed by $\mathrm{Y}_{-} \mathrm{ZrO}_{2}-\mathrm{A}$ and then cpTi-A; Sdr values between cpTi$\mathrm{A}, \mathrm{Y}-\mathrm{ZrO}_{2}-\mathrm{A}$ and $\mathrm{Mg}-\mathrm{ZrO}_{2}-\mathrm{A}$ were significantly different $(p<$ $0.05)$. Among sandblasted surfaces, $\mathrm{Y}^{-} \mathrm{ZrO}_{2}-\mathrm{S}$ had the significantly lowest Sa value, followed by cpTi-S and then $\mathrm{Mg}-\mathrm{ZrO}_{2}-\mathrm{S}(p$
$<0.05)$. On the other hand, $\mathrm{Y}_{-\mathrm{ZrO}_{2}}-\mathrm{S}$ had the lowest average $\mathrm{Sdr}$ value followed by $\mathrm{Mg}-\mathrm{ZrO}_{2}-\mathrm{S}$ and then cpTi-S; cpTi-S had a significantly higher $\mathrm{Sdr}$ value than both $\mathrm{Y}_{-} \mathrm{ZrO}_{2}-\mathrm{S}$ and $\mathrm{Mg}-$ $\mathrm{ZrO}_{2}$-S $(p<0.05)$.

The hydrophilicity of all surface-treated specimens prior to immersion in oral bacteria or seeding with mammalian host cells is listed in Table 2. Overall, all surfaces were relatively hydrophilic with average contact angles $\left(\theta_{c}\right) \leq 31^{\circ}$. In general, specimens wetted with cell culture media prior to seeding with mammalian host cells had lower average $\theta_{\mathrm{c}}$ values than corresponding surfaces that were cleaned post-surface treatment and used as is for bacterial immersion. Furthermore, all polished surfaces before exposure to oral bacteria or mammalian host cells generally had higher average $\theta_{\mathrm{c}}$ values than acid-etched or

Table 1 Mean arithmetic height, $\mathrm{Sa}(\mu \mathrm{m})$, and developed interfacial area ratio, $\mathrm{Sdr}(\%)$, of surface-treated $\mathrm{cpTi}, \mathrm{Y}-\mathrm{ZrO} \mathrm{O}_{2}$ and $\mathrm{Mg}-\mathrm{ZrO} \mathrm{O}_{2}$

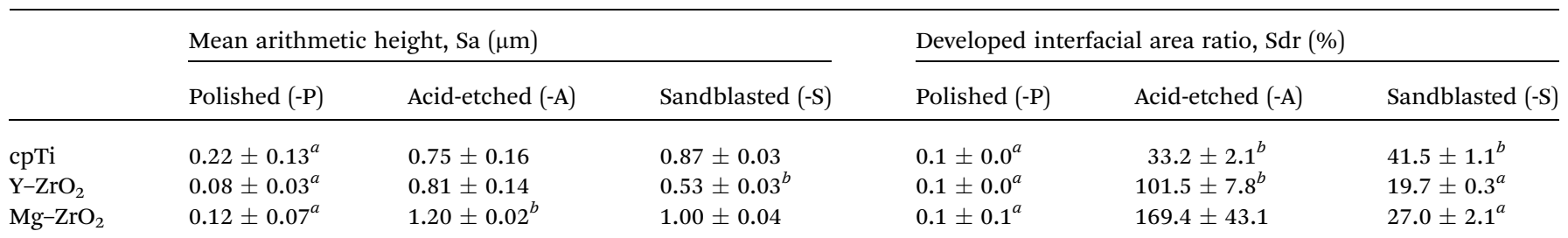

${ }^{a}$ Significantly different than other surfaces within material group. ${ }^{b}$ Significantly different than other materials within surface treatment group. 
Table 2 Contact angles, $\theta_{\mathrm{c}}\left({ }^{\circ}\right)$ of surface-treated $\mathrm{cpTi}, \mathrm{Y}-\mathrm{ZrO}_{2}$, and $\mathrm{Mg}-\mathrm{ZrO}_{2}$ specimens used for immersion with oral bacteria or seeding with mammalian host cells

\begin{tabular}{|c|c|c|c|c|c|c|}
\hline & Polished (-P) & Acid-etched (-A) & $\begin{array}{l}\text { Sandblasted } \\
(-S)\end{array}$ & Polished (-P) & Acid-etched (-A) & $\begin{array}{l}\text { Sandblasted } \\
(-S)\end{array}$ \\
\hline срTi & $31^{\circ} \pm 4^{a, d}$ & $20^{\circ} \pm 5^{e}$ & $15^{\circ} \pm 4$ & $14^{\circ} \pm 2^{b, d}$ & $10^{\circ} \pm 3$ & $8^{\circ} \pm 2$ \\
\hline $\mathrm{Y}-\mathrm{ZrO}_{2}$ & $24^{\circ} \pm 3$ & $11^{\circ} \pm 2^{a}$ & $27^{\circ} \pm 3^{e}$ & $9^{\circ} \pm 1$ & $9^{\circ} \pm 1$ & $8^{\circ} \pm 1$ \\
\hline $\mathrm{Mg}-\mathrm{ZrO}_{2}$ & $28^{\circ} \pm 2^{a}$ & $8^{\circ} \pm 1$ & $9^{\circ} \pm 2$ & $11^{\circ} \pm 2^{c}$ & $8^{\circ} \pm 3$ & $8^{\circ} \pm 1$ \\
\hline
\end{tabular}

${ }^{a}$ Significantly different than other surfaces within material group. ${ }^{b}$ Significantly higher than sandblasted (-S) surface within material group. ${ }^{c}$ Significantly higher than acid-etched (-A) surface within material group. ${ }^{d}$ Significantly higher than $\mathrm{Y}^{-} \mathrm{ZrO}_{2}$ within surface treatment group. ${ }^{e}$ Significantly different than other materials within surface treatment group.

sandblasted variants for each substrate material. Among specimens exposed to oral bacteria, both cpTi-P and $\mathrm{Mg}^{-} \mathrm{ZrO}_{2}-\mathrm{P}$ had a significantly higher $\theta_{\mathrm{c}}$ values than their acid-etched or sandblasted variants $(p<0.05)$. In contrast, $\mathrm{Y}-\mathrm{ZrO}_{2}-\mathrm{A}$ had a significantly lower average $\theta_{\mathrm{c}}$ value than $\mathrm{Y}-\mathrm{ZrO}_{2}-\mathrm{P}$ or $\mathrm{Y}-\mathrm{ZrO}_{2}$-S $(p<$ 0.05). Between polished surfaces, cpTi-P only had a statistically higher $\theta_{\mathrm{c}}$ value than $\mathrm{Y}-\mathrm{ZrO}_{2}-\mathrm{P}$; for acid-etched surfaces, cpTi-A had a significantly higher $\theta_{\mathrm{c}}$ value than both $\mathrm{Y}^{-} \mathrm{ZrO}_{2}-\mathrm{A}$ and $\mathrm{Mg}-\mathrm{ZrO}_{2}$-A while $\mathrm{Y}-\mathrm{ZrO}_{2}$-S had the statistically highest value as compared to cpTi-S or $\mathrm{Mg}-\mathrm{ZrO}_{2}-\mathrm{S}(p<0.05)$. Among specimens wetted with cell culture media prior to seeding with mammalian host cells, cpTi-P only had significantly higher $\theta_{c}$ value than cpTi-S $(p<0.05)$. No statistical difference in $\theta_{\mathrm{c}}$ values was observed between surface treatments for $\mathrm{Y}^{-} \mathrm{ZrO}_{2}$ while $\mathrm{Mg}-$ $\mathrm{ZrO}_{2}-\mathrm{A}$ was only significantly lower than $\mathrm{Mg}-\mathrm{ZrO}_{2}-\mathrm{P}(p<0.05)$. Between polished surfaces, cpTi-P had significantly higher $\theta_{\mathrm{c}}$ values than both $\mathrm{Y}-\mathrm{ZrO}_{2}-\mathrm{P}$ and $\mathrm{Mg}-\mathrm{ZrO}_{2}-\mathrm{P}(p<0.05)$; however, no statistical significance was seen between acid-etched or sandblasted surfaces $(p>0.05)$.

For each surface treatment-substrate material combination, the mean arithmetic height (Sa) and developed interfacial area ratio (Sdr) were calculated to assess surface roughness while contact angles were measured to quantify surface hydrophilicity. As shown in Table 1, surface roughness was higher on acid-etched (Sa: 0.75-1.20 $\mu \mathrm{m}$ ) and sandblasted (Sa: 0.53-1.00 $\mu \mathrm{m})$ surface variants as compared to polished surfaces (Sa: $0.08-$ $0.22 \mu \mathrm{m})$ which corroborated qualitative observations made with SEM (Fig. 1). Additionally, increasing Sa values correlated with increasing Sdr values for all specimens; specifically, polished surfaces only demonstrated an average increase of $0.1 \%$ in surface area due to surface treatment while acid-etched and sandblasted surfaces exhibited $33.2-169.4 \%$ and $19.7-41.5 \%$ increase in surface area, respectively. For cpTi, sandblasting led to a rougher surface on average than acid-etching while for both $\mathrm{Y}-\mathrm{ZrO}_{2}$ and $\mathrm{Mg}-\mathrm{ZrO}_{2}$, the reverse trend was observed. This behavior can be explained due to $\mathrm{Y}-\mathrm{ZrO}_{2}$ and $\mathrm{Mg}-\mathrm{ZrO}_{2}$ being relatively harder than cpTi, which is a relatively soft metal. Furthermore, sandblasting was performed with relatively small alumina particles $(50 \mu \mathrm{m})$ which led to lower surface roughness for $\mathrm{Y}-\mathrm{ZrO}_{2}$ and $\mathrm{Mg}-\mathrm{ZrO}_{2}$ as compared to acid-etching with $40 \%$ hydrofluoric acid in the present study. Wassmann et al. reported similar values in surface roughness for cpTi and Y$\mathrm{ZrO}_{2}$ after polishing $\left(R_{\mathrm{a}}: 0.05-0.09 \mu \mathrm{m}\right)$ and sandblasting with $50 \mu \mathrm{m}$ alumina particles $\left(R_{\mathrm{a}}: 0.49-0.83 \mu \mathrm{m}\right) .^{39}$ Moreover, higher Ra values were also observed for sandblasted cpTi surfaces relative to sandblasted $\mathrm{Y}^{-\mathrm{ZrO}_{2}}$ variants. ${ }^{39}$ Interestingly, all surface-treated substrates in the present study were relatively hydrophilic with average contact angles $\left(\theta_{c}\right)$ being $31^{\circ}$ or less (Table 2). In contrast, Wassmann et al. modified the surface of polished and sandblasted cpTi and $\mathrm{Y}^{-} \mathrm{ZrO}_{2}$, to yield hydrophilic variants, but the lowest $\theta_{\mathrm{c}}$ value achieved was $41.4^{\circ} \pm 2.5{ }^{39} \mathrm{As}$ opposed to the present study, polished surfaces (41.4-65.2 $\left.{ }^{\circ}\right)$ were more hydrophilic than their sandblasted counterparts $\left(60.7-107.6^{\circ}\right){ }^{39}$ Similarly, Zhao et al. also found polished cpTi and $\mathrm{Y}^{-\mathrm{ZrO}_{2}}\left(53-55^{\circ}\right)$ to be more hydrophilic than acid-etched ones $\left(81-82^{\circ}\right) .^{46}$ This behavior may be explained due to the cleaning methods used in the present study, which reduced adventitious carbon on samples exposed to ambient air by ultrasonication and oven drying. Without sufficient cleaning, samples with greater surface roughness (acid-etched and sandblasted) would attract more carbon contamination, which may have increased hydrophobicity to a greater extent than polished surfaces in previous studies.

\subsection{Early-colonizing bacterial adhesion}

To assess the influence of substrate and surface treatment combination on bacterial biofilm growth, surface-treated cpTi, $\mathrm{Y}-\mathrm{ZrO}_{2}$, and $\mathrm{Mg}-\mathrm{ZrO}_{2}$ were immersed in a monoculture of $S$. mutans, S. sanguinis, and S. salivarius, as well as a polyculture of all three. Relative early-colonizing bacterial adhesion on all specimens after 1 and 3 days is illustrated in Fig. 2. Overall, bacterial adhesion increased on average from 1 to 3 days between corresponding groups immersed in S. sanguinis and $S$. salivarius but was only significantly different for $S$. sanguinis on cpTi-P $(p<0.05)$. In contrast, $S$. mutans and the polyculture exhibited no distinct increase in relative adherent bacteria with increasing time. For $S$. sanguinis, adherent bacterial count increased with apparent increasing surface roughness for cpTi and both $\mathrm{Y}-\mathrm{ZrO}_{2}$ and $\mathrm{Mg}-\mathrm{ZrO}_{2}$. Specifically, sandblasted specimens yielded the highest average adherent bacterial count followed by acid-etched and polished specimens after 1 day. Similarly, the bacterial count for $S$. salivarius was greater on 
(A)

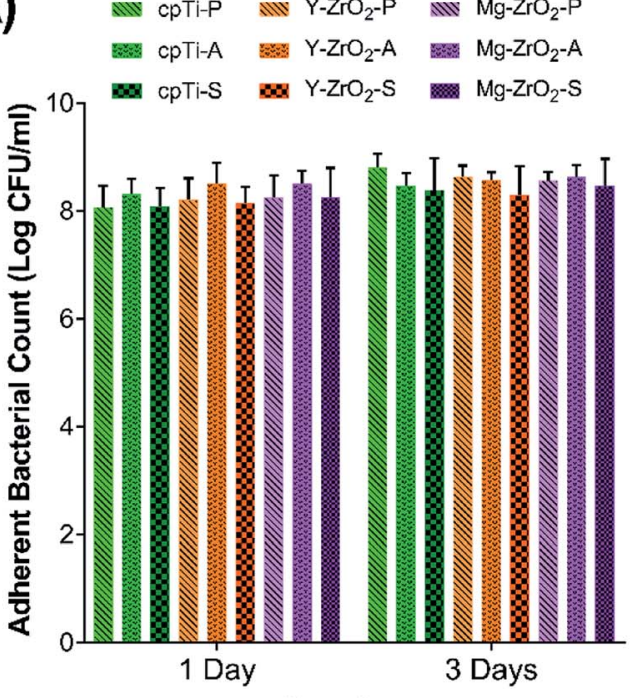

S. mutans

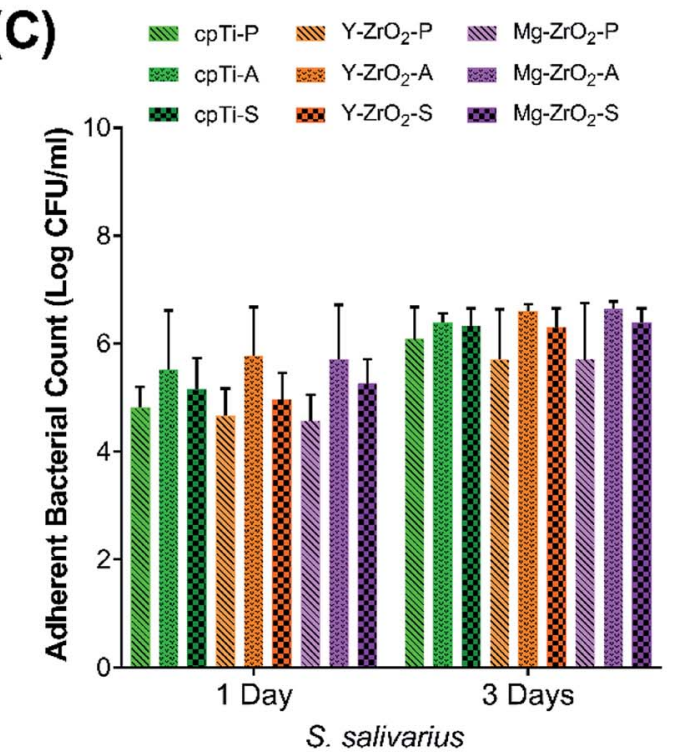

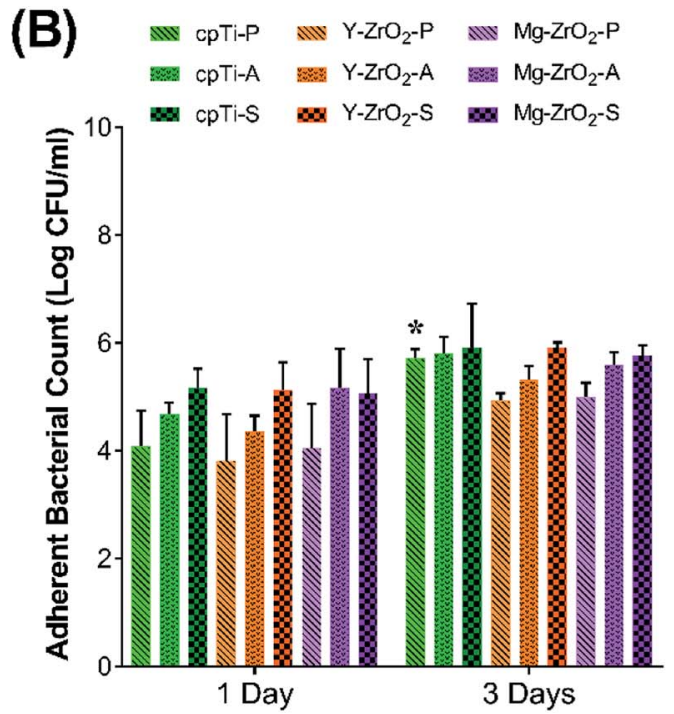

S. sanguinis

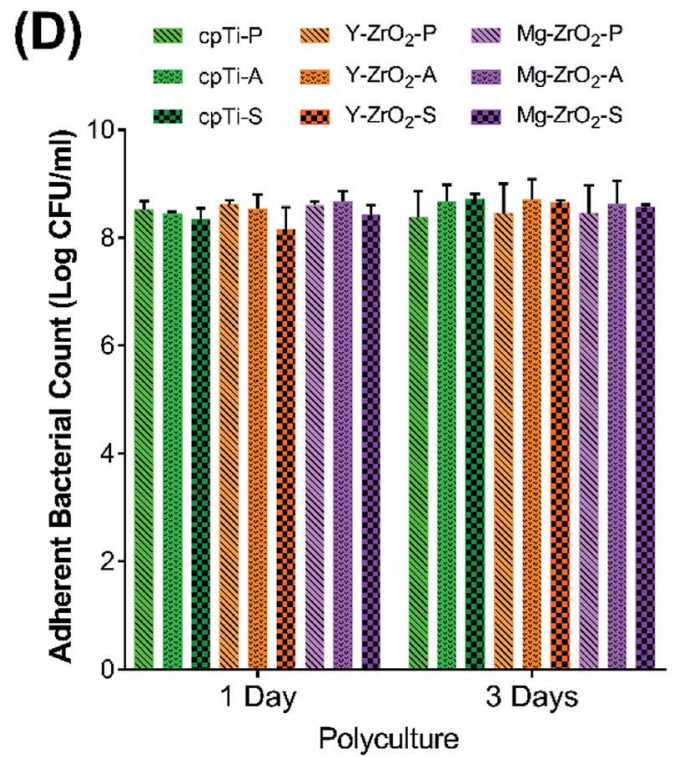

Fig. 2 Adherent bacterial count of Streptococcus monoculture: (A) S. mutans, (B) S. sanguinis, (C) S. salivarius, and (D) Streptococcus polyculture on polished (-P), acid-etched (-A), and sandblasted (-S) $\mathrm{cpTi}, \mathrm{Y}-\mathrm{ZrO}_{2}$, and $\mathrm{Mg}-\mathrm{ZrO}_{2}$ after 1 and 3 days. * denotes statistical significance between marked group after 3 days and corresponding group after 1 day of immersion.

rougher surface variants after 1 day but was highest on acidetched surfaces, followed by sandblasted and then polished surfaces. However, this trend was less apparent after 3 days for adherent S. sanguinis and S. salivarius. In summary, earlycolonizing Streptococcus adhesion did not differ between surface-treated cpTi, $\mathrm{Y}-\mathrm{ZrO}_{2}$, and $\mathrm{Mg}-\mathrm{ZrO}_{2}$.

In general, bacterial adhesion increased on average from 1 to 3 days for $S$. sanguinis and $S$. salivarius but was only statistically significant for cpTi-P immersed in $S$. sanguinis, indicating that bacterial biofilm growth and attachment was still developing after 1 day (Fig. 2). On the other hand, adherent $S$. mutans count did not increase between 1 and 3 days, demonstrating that $S$. mutans had saturated the surface by 1 day of growth under the current test conditions. Between strains, S. mutans achieved significantly higher adherent bacterial count which resulted in 100-10 000 times more adherent bacteria as compared to $S$. sanguinis and $S$. salivarius. However, this behavior was partially due to the greater carrying capacity of the media used in the present study for $S$. mutans as compared to the other Streptococcus species. That is, adherent bacterial counts for all Streptococcus strains were closer in value to each other when normalizing relative to planktonic bacterial count. Interestingly, both adherent $S$. sanguinis and $S$. salivarius count was found to be higher on acid-etched and sandblasted surfaces which had significantly greater surface roughness (Sa and Sdr values) versus polished ones, irrespective of the substrate 
material. This behavior was expected as increasing the surface roughness increases the surface area which provides more attachment sites for bacterial adhesion, thus yielding higher bacterial counts. Ultimately, bacterial adhesion did not significantly differ between cpTi, $\mathrm{Y}-\mathrm{ZrO}_{2}$, and $\mathrm{Mg}-\mathrm{ZrO}_{2}$, suggesting that none of the substrate materials promoted bacterial adhesion.

In order to reconcile differences between outcomes observed in the literature and the current study, the manner in which bacterial adhesion and biofilm growth is assessed must be considered. In the present work, bacterial adhesion was quantified by enumerating viable adherent bacterial colonies. In contrast, other studies have evaluated bacterial attachment based on bacterial biofilm coverage and its dimensions. For example, Ismail et al. concluded that $\mathrm{ZrO}_{2}$ surfaces retained less average biofilm height and surface coverage than their cpTi counterparts after 14 days in vivo. ${ }^{35}$ Similarly, Roehling et al. demonstrated a significant reduction in plaque thickness in vitro on $\mathrm{ZrO}_{2}$ as compared to cpTi using bacteria derived from human patients as well as with a three species-biofilm consisting of $S$. sanguinis, Fusobacterium nucleatum, and $P$. gingivalis on $\mathrm{ZrO}_{2} \cdot{ }^{34}$ Likewise, another study directly counted significantly lower number of $S$. mutans colonies using SEM on polished $\mathrm{ZrO}_{2}$ specimens relative to a titanium alloy after $24 \mathrm{~h}$ of immersion. ${ }^{40}$ However, a study by Zhao et al. evaluating polished, machined, and acid-etched cpTi and $\mathrm{Y}-\mathrm{ZrO}_{2}$ observed that $\mathrm{Y}-\mathrm{ZrO}_{2}$ variants had the most monoculture biofilm volume of three Streptococcus species and Staphylococcus aureus under fluid-flow conditions. $^{36}$ On the other hand, Lee et al. did not find any statistical difference in biofilm formation of $S$. sanguinis on cpTi and $\mathrm{Y}-\mathrm{ZrO}_{2}$ after $4 \mathrm{~h}$ of growth using a crystal violet assay to quantify the amount of biofilm. ${ }^{37}$

In addition to substrate material, surface roughness and topography after applied surface treatments can influence bacterial adhesion. In the present study, S. sanguinis consistently achieved higher average adherent bacterial count on sandblasted surfaces $v s$. acid-etched ones while the opposite trend was observed for $S$. salivarius. This behavior was observed despite both acid-etched and sandblasted surface variants having comparable surface roughness (Sa and Sdr values) and hydrophilicity $\left(\theta_{\mathrm{c}}\right)$. Thus, differences in surface morphology such as the pits on acid-etched surfaces as compared to the sharp, jagged peaks on sandblasted surfaces (Fig. 1) influenced the number of adherent bacteria and may favor attachment depending on the bacterial species. Similarly, Wassmann et al. concluded that increasing surface roughness on sandblasted $\operatorname{cpTi}\left(R_{\mathrm{a}}: 0.83 \pm 0.06 \mu \mathrm{m}, 2.98 \pm 0.31 \mu \mathrm{m}\right)$ and $\mathrm{Y}-\mathrm{ZrO}_{2}\left(R_{\mathrm{a}}: 0.49 \pm\right.$ $0.03 \mu \mathrm{m}, 1.32 \pm 0.10 \mu \mathrm{m})$ led to increased adhesion of $S$. sanguinis after a 2 hour immersion relative to polished variants (cpTi: $0.09 \pm 0.02 \mu \mathrm{m} ; \mathrm{ZrO}_{2}: 0.05 \pm 0.02 \mu \mathrm{m}$ ) but did not affect attachment of Staphylococcus epidermidis on either cpTi or $\mathrm{ZrO}_{2}$ under the same test conditions, which further demonstrated that the influence of surface roughness on bacterial adhesion is strain dependent. ${ }^{39}$ In contrast to the present study, significantly more $S$. sanguinis adhered to $\mathrm{Y}-\mathrm{ZrO}_{2}$ than cpTi. ${ }^{39}$ However, this behavior may be attributed to differences in experimental methodology including immersion duration in bacterial media, use of a fluorescent dye to quantify adherent bacteria, and immersion of the samples in artificial saliva to form a salivary pellicle prior to immersion with bacteria. Corroborating the trend observed for S. sanguinis in the present study, Almaguer-Flores et al. determined that sandblasted and acid-etched cpTi $\left(R_{\mathrm{a}}=3.2 \mu \mathrm{m}\right)$ achieved significantly higher proportions of $S$. sanguinis adhesion after $24 \mathrm{~h}$ using a ninespecies polyculture biofilm model on cpTi as compared to only acid-etched $\left(R_{\mathrm{a}}<0.8 \mu \mathrm{m}\right)$ and pretreated $\left(R_{\mathrm{a}}<0.2 \mu \mathrm{m}\right)$ surfaces. ${ }^{41}$

\subsection{Mammalian cellular growth}

To evaluate the ability of mammalian cells to grow on all surface-treated substrates, cellular proliferation was quantified and compared across different time points. Relative human macrophage proliferation after 1 and 3 days on all specimens is depicted in Fig. 3. In general, average macrophage proliferation was found to slightly increase between 1 and 3 days but not significantly when comparing corresponding groups $(p>0.05)$. After 1 day, cpTi-A showed the highest average macrophage proliferation and was significantly higher than all other groups except for cpTi-P and $\mathrm{Mg}-\mathrm{ZrO}_{2}-\mathrm{S}(p<0.05)$. After 3 days, average macrophage proliferation was still the highest on cpTi-A but not significantly amongst all other groups $(p>0.05)$. However, cpTiA after 3 days was observed to have significantly higher macrophage proliferation than 1 day values for $\mathrm{Y}-\mathrm{ZrO}_{2}-\mathrm{A}$ and $\mathrm{Mg}-\mathrm{ZrO}_{2}-\mathrm{P}(p<0.05)$.

The relative proliferation of fibroblasts on all surface-treated specimens after 1, 3, and 7 days is illustrated in Fig. 4. As observed for macrophages, the highest average fibroblast

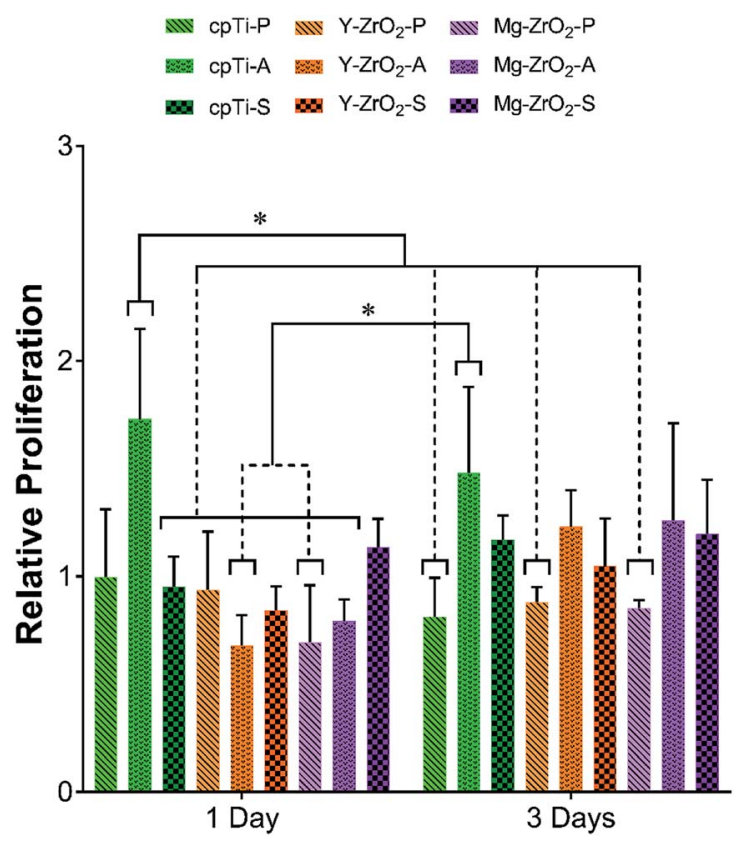

Fig. 3 Relative proliferation of human macrophages on polished (-P), acid-etched (-A), and sandblasted (-S) $\mathrm{cpTi}, \mathrm{Y}-\mathrm{ZrO}_{2}$, and $\mathrm{Mg}-\mathrm{ZrO}_{2}$ after 1 and 3 days $(n=3)$. * denotes statistical significance between all pairwise combinations $(\alpha=0.05)$. 
proliferation after 1 and 3 days was found on cpTi-A. Specifically, 1 day cpTi-A demonstrated significantly higher fibroblast proliferation than all other 1 day groups except for $\mathrm{Y}-\mathrm{ZrO}_{2}-\mathrm{P}(p<$ 0.05). By 3 days, however, cpTi-A only showed significantly higher fibroblast proliferation than cpTi-P and $\mathrm{Y}-\mathrm{ZrO}_{2}-\mathrm{P}$ and both $\mathrm{Y}-\mathrm{ZrO}_{2}-\mathrm{S}$ and $\mathrm{Mg}-\mathrm{ZrO}_{2}-\mathrm{S}(p<0.05)$. After 7 days, average fibroblast proliferation increased to a similar level for all specimen groups. Although fibroblast proliferation generally increased over time, only 7 day cpTi-P as well as cpTi-S, Y-ZrO ${ }_{2}$ $\mathrm{S}$, and $\mathrm{Mg}-\mathrm{ZrO}_{2}-\mathrm{S}$ demonstrated significantly higher fibroblast proliferation than their corresponding 1 day values $(p<0.05)$. Furthermore, when comparing corresponding fibroblast proliferation values after 3 and 7 days, only cpTi-P had significantly higher fibroblast proliferation than its 3 day counterpart $(p<0.05)$.

The relative proliferation of pre-osteoblasts after 1,3 , and 7 days on surface-treated substrates is depicted in Fig. 5. Overall, average pre-osteoblast proliferation increased between 1, 3, and 7 days. Pre-osteoblast proliferation after 7 days was significantly higher than all corresponding groups at 1 day $(p<0.05)$. Similarly, pre-osteoblast proliferation after 7 days was significantly higher than all corresponding groups at 3 days except for $\mathrm{Y}-$ $\mathrm{ZrO}_{2}-\mathrm{P}(p<0.05)$. In general, average pre-osteoblast proliferation after 1 and 3 days was highest on polished surfaces followed by sandblasted and then acid-etched substrates but was not significantly different $(p>0.05)$. By 7 days, average preosteoblast proliferation leveled out to statistically similar levels of growth on all substrates $(p>0.05)$ and, on average, was highest on $\mathrm{Mg}-\mathrm{ZrO}_{2}-\mathrm{P}$.

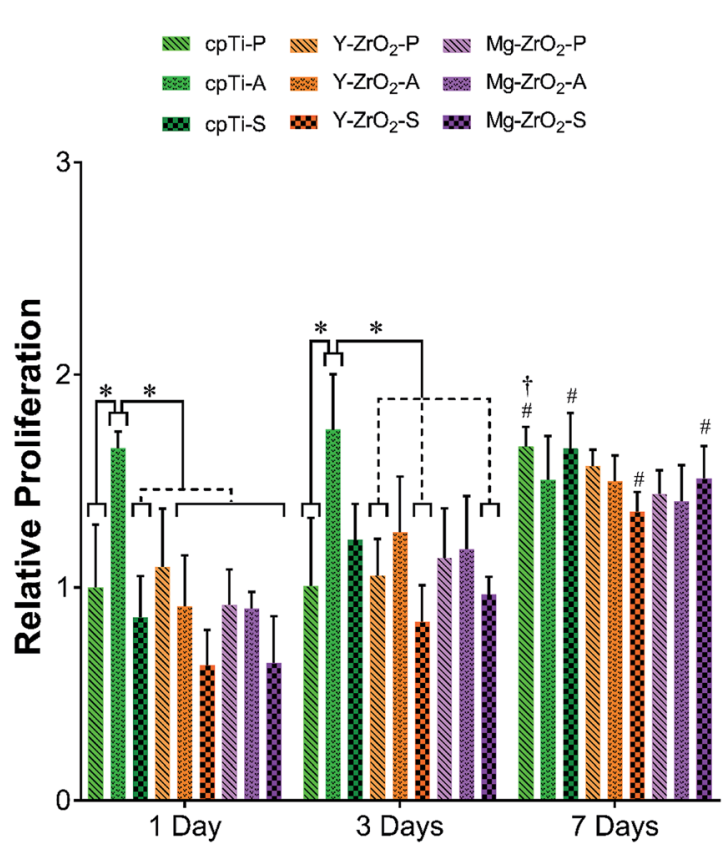

Fig. 4 Relative proliferation of human gingival fibroblasts (HGF-1) on polished (-P), acid-etched (-A), and sandblasted (-S) $\mathrm{cpTi}, \mathrm{Y}-\mathrm{ZrO}_{2}$, and $\mathrm{Mg}-\mathrm{ZrO}_{2}$ after 1,3 , and 7 days $(n=3) . *$ denotes statistical significance between all pairwise combinations. " denotes significance between marked group vs. corresponding 1 day timepoint. ${ }^{\dagger}$ denotes significance between marked group vs. corresponding 3 day timepoint $(\alpha=$ $0.05)$.

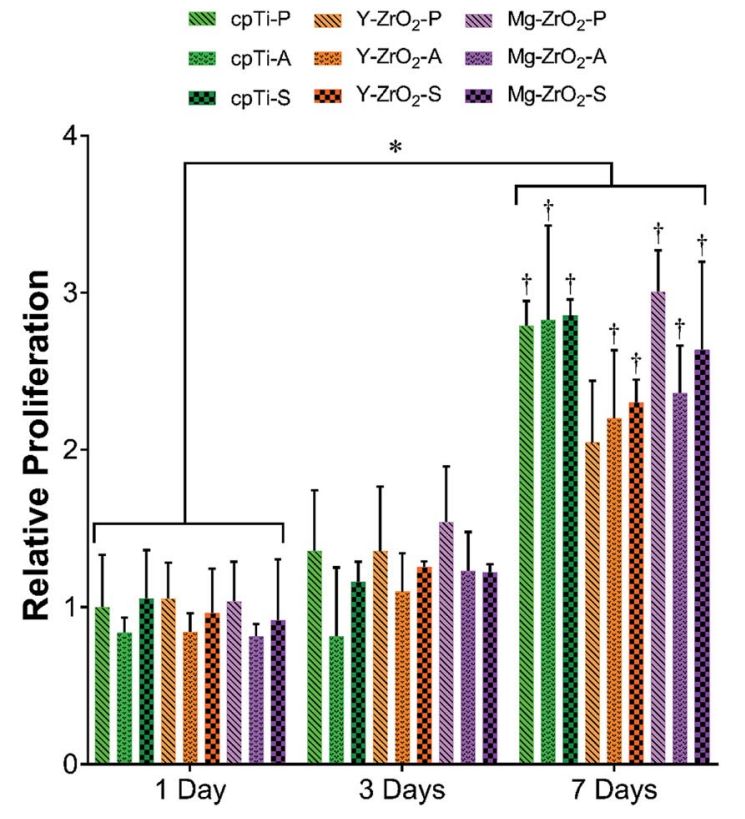

Fig. 5 Relative proliferation of murine pre-osteoblasts (MC3T3-E1) on polished (-P), acid-etched (-A), and sandblasted (-S) $\mathrm{cpTi}, \mathrm{Y}-\mathrm{ZrO}_{2}$, and $\mathrm{Mg}-\mathrm{ZrO}_{2}$ after 1,3 , and 7 days $(n=3) . *$ denotes statistical significance between all pairwise combinations. ${ }^{\dagger}$ denotes significance between marked group vs. corresponding 3 day timepoint $(\alpha=0.05$ ).

The fold change in ALP activity of pre-osteoblasts is depicted in Fig. 6. Overall, ALP activity of pre-osteoblasts increased over the course of 7,10 , and 14 days but was found to be at statistically similar values between groups within each timepoint $(p>0.05)$. By 14 days, acid-etched and sandblasted surfaces generally demonstrated higher average ALP activity as compared to polished surfaces for each substrate. Between 7 and 10 days, no significant difference was found in ALP activity between corresponding groups $(p>0.05)$. However, a significant increase in ALP activity was found on all acid-etched and sandblasted surface variants between 7 days and 14 days, excluding $\mathrm{Mg}-\mathrm{ZrO}_{2}-\mathrm{S}(p<0.05)$. Furthermore, cpTi-S and $\mathrm{Mg}-\mathrm{ZrO}_{2}$-A demonstrated a significant increase in ALP activity from 10 to 14 days $(p<0.05)$. In contrast, no significant difference in ALP activity was observed on polished substrates between different timepoints $(p>0.05)$.

Confocal microscopy imaging of fluorescently-stained cells after 1 day is depicted in Fig. 7 and after 3 and 7 days in Fig. S1 and S2. $\dagger$ In general, macrophages, fibroblasts, and preosteoblasts showed no noticeable differences in apparent surface coverage or cellular morphology between different substrate materials and time points but varied in morphology based on the applied surface treatment. Mammalian cells, especially macrophages (Fig. 1, S1, S2A-C, J-L and S-U†), appeared more spread and flattened on polished surfaces with most actin filaments parallel to the surface. On the other hand, all mammalian cells on acid-etched (Fig. 1, S1, S2D-F, M-O and $\mathrm{V}-\mathrm{X}^{\dagger}$ ) and sandblasted (Fig. 1, S1, S2G-I, P-R and $\mathrm{Y}-\mathrm{AA} \dagger$ ) surfaces exhibited a more spindle-like shape with a greater distribution of actin filaments attached to the surface at different angles. 


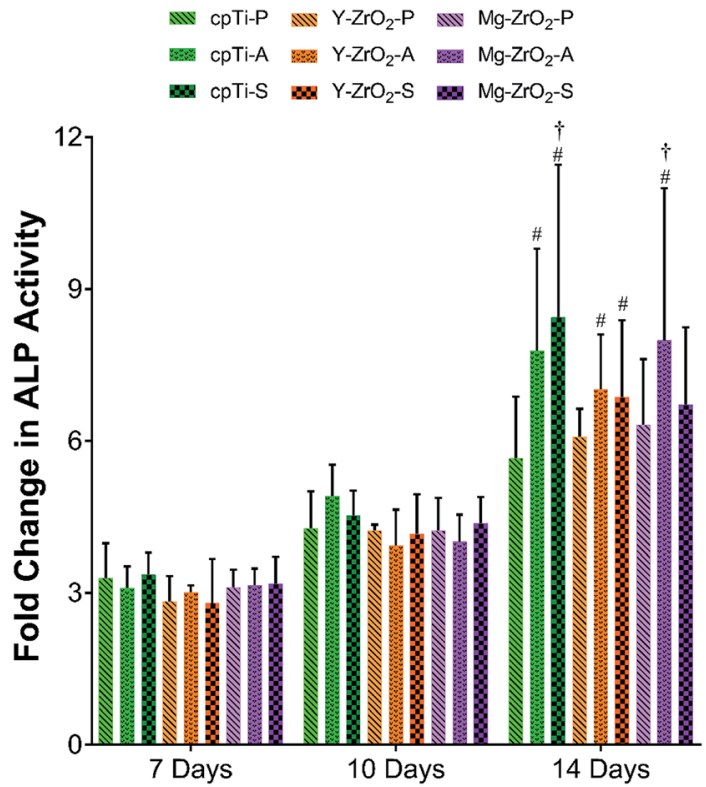

Fig. 6 Fold change in ALP activity of murine pre-osteoblasts (MC3T3E1) on polished (-P), acid-etched (-A), and sandblasted (-S) cpTi, Y$\mathrm{ZrO}_{2}$, and $\mathrm{Mg}-\mathrm{ZrO}_{2}$ after 1,3 , and 7 days $(n=3)$. * denotes statistical significance between all pairwise combinations. ${ }^{*}$ denotes significance between marked group vs. corresponding 7 day timepoint. ${ }^{\dagger}$ denotes significance between marked group vs. corresponding 10 day timepoint $(\alpha=0.05)$.

In addition to evaluating oral bacterial adhesion, understanding host tissue response to cpTi and $\mathrm{ZrO}_{2}$ is crucial to assessing material performance in vivo. In order to assess the effect of both substrate material and surface treatment on mammalian cellular proliferation and differentiation, mammalian cells were directly seeded onto the specimens as opposed to performing indirect contact viability tests. Three different types of host cells expected to encounter the dental implant surface during wound healing post-implantation were selected: macrophages, fibroblasts, and pre-osteoblasts, which represented the immune, soft-tissue, and bone-tissue response, respectively. Based on previous literature, it was hypothesized that both $\mathrm{Y}-\mathrm{ZrO}_{2}$ and $\mathrm{M}$ $\mathrm{ZrO}_{2}$ would demonstrate higher cellular proliferation as compared to cpTi. Also, it was hypothesized that acid-etched and sandblasted surfaces would have higher cellular proliferation as compared to smooth, polished surfaces.

To assess cellular proliferation across different time points, all measured values of a set were normalized to the proliferation of each cell line on 1 day cpTi-P. Macrophage proliferation showed a general increase from 1 day to 3 days but did not have a significant increase between corresponding groups (Fig. 3). Corroborating this trend, the density of fluorescently-stained macrophages on all surfaces appeared to be similar after 1 and 3 days (Fig. 7 and S1A-I†). Among all surface-treated substrates, however, cpTi-A demonstrated the highest macrophage proliferation after both 1 and 3 days (Fig. 3). This trend was similarly observed for fibroblasts grown on cpTi-A after 1 and 3 days (Fig. 4). In contrast, pre-osteoblasts demonstrated the lowest average proliferation on cpTi-A after 1 and 3 days. As explained previously for oral bacteria, these observations could be attributed to differences in the surface topography of polished, acid-etched, and sandblasted specimens. In Fig. 1B, cpTiA surfaces exhibited micro-pits and uniform distribution of distinct peaks and valleys, which acted as surfaces cues and preferentially stimulated the growth of macrophages and fibroblasts. In another study, Köunönen et al. also reported greater average fibroblast proliferation on acid-etched cpTi as compared to sandblasted cpTi. ${ }^{58}$ On the other hand, the presence of these micro-pits resulted in a marginal decrease in preosteoblast proliferation in the present study as compared to polished and sandblasted surfaces (Fig. 5). In a previous study by Carvalho et al., acid-etched cpTi also resulted in significantly lower osteoblast proliferation but not viability as compared to machined cpTi surfaces after 7 days. ${ }^{59}$ In contrast, cpTi-S and Y$\mathrm{ZrO}_{2}$-S, despite also being rough to a similar extent as acid-

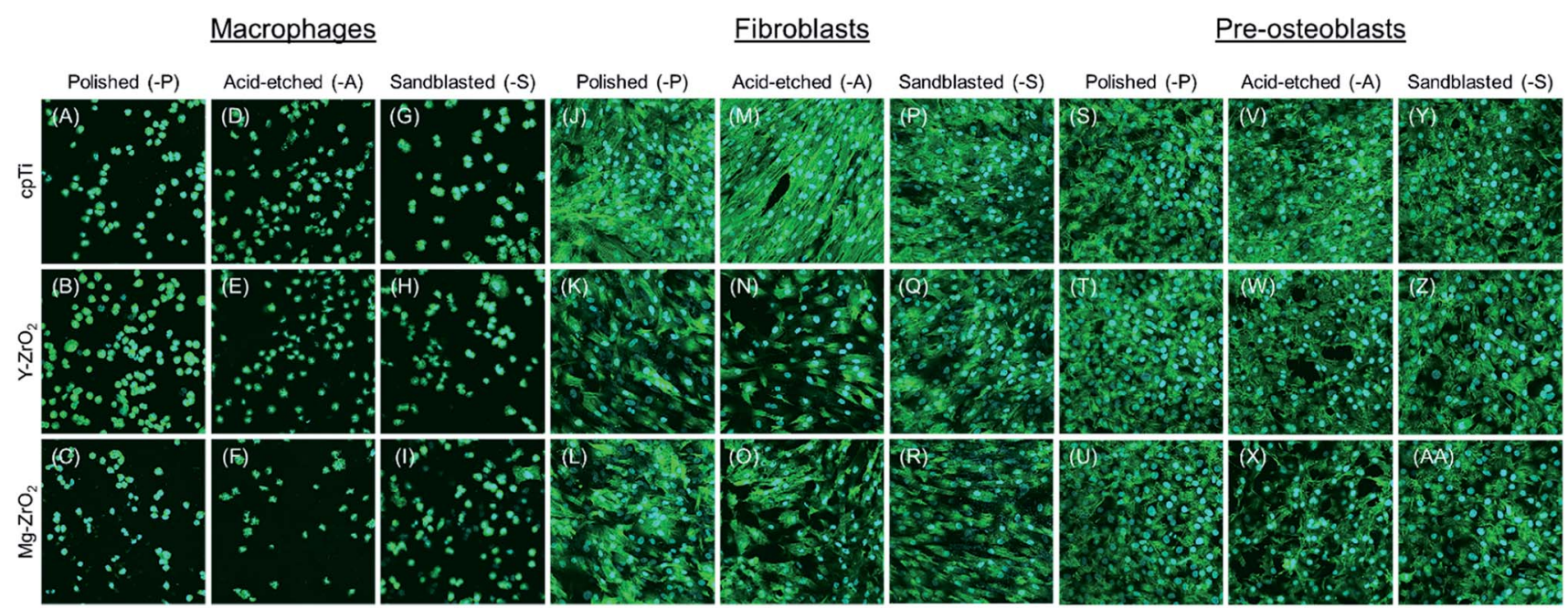

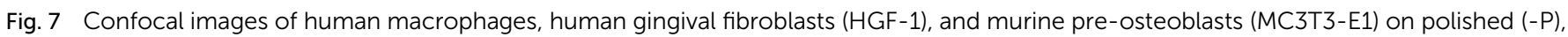
acid-etched (-A), and sandblasted (-S) cpTi, $\mathrm{Y}-\mathrm{ZrO}_{2}$, and $\mathrm{Mg}-\mathrm{ZrO}_{2}$ after 1 day of growth. 
etched ones (Table 1), exhibited more irregular and sharp surface features (Fig. 1C, F and I), as was observed in a previous study, ${ }^{60}$ while polished surfaces were mostly smooth and exhibited few surface defects and superficial scratches (Fig. 1A, $\mathrm{D}$ and $\mathrm{G})$. However, by 7 days, no significant differences in both fibroblast and pre-osteoblast proliferation were observed between the different surface-treated cpTi, $\mathrm{Y}-\mathrm{ZrO}_{2}$, and $\mathrm{Mg}$ $\mathrm{ZrO}_{2}$ surfaces (Fig. 4 and 5), which matched trends observed for cpTi and $\mathrm{Y}-\mathrm{ZrO}_{2}$ surfaces in previous studies. ${ }^{\mathbf{5 4 , 6 1}}$ Thus, cpTi, Y$\mathrm{ZrO}_{2}$, and $\mathrm{Mg}-\mathrm{ZrO}_{2}$ were ultimately suitable for mammalian cell growth, irrespective of applied polishing, acid-etching, and sandblasting surface treatment. This result was further supported by observations of similar attachment and relative number of fibroblasts and pre-osteoblasts on all cpTi, $\mathrm{Y}-\mathrm{ZrO}_{2}$, and $\mathrm{Mg}-\mathrm{ZrO}_{2}$ surfaces after 7 days (Fig. S2 $\dagger$ ).

As observed in the present work, mammalian cellular proliferation was shown to be comparable or greater on $\mathrm{Y}-\mathrm{ZrO}_{2}$ surfaces as compared to cpTi. For instance, Wang et al. performed an analysis of macrophage behavior on multiple variants of surface-treated $\mathrm{Y}-\mathrm{ZrO}_{2}$, cpTi, and a titanium-zirconium alloy (TiZr). ${ }^{45}$ In this study, similar macrophage proliferation was found on all implant surfaces; however, hydrophilic surfaces demonstrated lower pro-inflammatory responses based on gene expression levels. ${ }^{45}$ Similarly, Zhao et al. evaluated cellular proliferation of osteoblasts and fibroblasts on various surface-modified cpTi and $\mathrm{Y}-\mathrm{ZrO}_{2}$ and found no significant difference in proliferation across substrate materials and surface modifications in the absence of bacteria. $^{36}$ However, Nothdurft et al. showed that fibroblast proliferation was higher on $\mathrm{Y}-\mathrm{ZrO}_{2}$ and demonstrated increased cell spreading on polished surfaces as opposed to rougher surfaces. ${ }^{47}$ Similarly, Depprich et al. found that osteoblast proliferation was significantly higher on $\mathrm{Y}-\mathrm{ZrO}_{2}$ specimens as compared to cpTi ones after 3 and 5 days of proliferation. ${ }^{48}$

Moreover, surface topography and roughness have also been shown to regulate host cell proliferation in previous studies. For example, Al Qahtani et al. demonstrated that adhesion of human osteoblast-like cells was most favorable for the roughest $\mathrm{Y}-\mathrm{ZrO}_{2}$ surface that was tested - sandblasting with $250 \mu \mathrm{m}$ particles. $^{50}$ Zareidoost et al. also found that rougher cpTi surfaces promoted attachment and proliferation of osteoblasts as compared to polished surfaces. ${ }^{51}$ At the same time, other studies have found no difference in cellular growth based on surface roughness. For example, Gruber et al. found that creating a rougher $\mathrm{Y}-\mathrm{ZrO}_{2}$ surface by acid-etching did not make a substantial difference in pre-osteoblast proliferation. ${ }^{52}$ Furthermore, variations in the hydrophilicity and roughness exist amongst these surface treatments. Generally, sandblasting, acid-etching, or polishing can yield a macro-rough $\left(R_{\mathrm{a}}\right.$ : $>10 \mu \mathrm{m})$, micro-rough $\left(R_{\mathrm{a}}: 1-10 \mu \mathrm{m}\right)$, or nano-rough $\left(R_{\mathrm{a}}:<1 \mu \mathrm{m}\right)$ surface, respectively. ${ }^{62}$ In the present study, polished surfaces had low surface roughness (Sa and Sdr values) while acid-etched and sandblasted surfaces had significantly higher values as previously explained. Also, hydrophilicity has been shown to be an indicator of cellular attachment with mammalian cells preferring more hydrophilic surfaces. ${ }^{63,64}$ However, all surfaces in the present study were relatively hydrophilic and thus could not account for differences observed in mammalian host cell behavior. Although surface roughness and hydrophilicity can influence each other, surface modifications can tune the hydrophilicity of both cpTi and $\mathrm{ZrO}_{2}$, independent of its surface roughness. ${ }^{65,66}$ For instance, sandblasted and acid-etched (SLA) cpTi dental implants possess a significantly more hydrophilic, modified SLA (modSLA) surface, which improved bone cell response in vitro and in vivo. ${ }^{67}$

Aside from proliferation, pre-osteoblasts demonstrated an increase in differentiation as measured by the increase in fold change of ALP activity over the span of 7, 10, and 14 days (Fig. 6). Although no significant difference in ALP activity was found between different surfaces for a given time point, rougher surfaces (acid-etched and sandblasted) generally resulted in higher ALP activity of pre-osteoblasts as compared to their smooth, polished counterparts. Pre-osteoblasts had significantly increased ALP activity on all acid-etched and sandblasted substrates after 14 days as compared to 7 days, excluding $\mathrm{Mg}-$ $\mathrm{ZrO}_{2}$-S. Moreover, the extent to which ALP activity had increased for pre-osteoblasts on cpTi-S and $\mathrm{Mg}-\mathrm{ZrO}_{2}-\mathrm{A}$ after 14 days resulted in significantly higher values than corresponding 10 day values. In a previous study, Muñoz et al. showed that a rough cpTi surface post-laser surface treatment $\left(R_{\mathrm{a}}: 10.57 \pm\right.$ $0.39 \mu \mathrm{m})$ as compared to smooth (polished) ones $\left(R_{\mathrm{a}}: 0.32 \pm\right.$ $0.01 \mu \mathrm{m})$ resulted in greater ALP activity as well as higher expression of osteoblastic phenotype markers. ${ }^{68}$ Yin et al. also observed higher average ALP activity as well as upregulation in osteoblast gene expression of human osteoblast-like cells on rough $\mathrm{Ti}$ alloy surfaces after electrochemically etching or sandblasting and acid-etching as compared to machined (smooth) surfaces. ${ }^{69}$ Furthermore, an increase in surface roughness was also shown to yield similar ALP activity levels for both sandblasted and acid-etched cpTi and $\mathrm{Y}-\mathrm{ZrO}_{2}$ surfaces after 8,11 , and 15 days. $^{70}$ Thus, it is expected that both rough cpTi and $\mathrm{Y}-\mathrm{ZrO}_{2}$ surfaces would allow for better bone growth and ultimately osseointegration in vivo.

Although the present study systematically evaluated the combination of surface treatment and substrate material on oral bacterial adhesion and mammalian cell growth, several limitations still need to be addressed in future works. Beginning with early-colonizing bacterial adhesion, one major limitation was the use of static fluid immersion; the use of a continuous fluid flow model would generate shear stresses which oppose bacterial attachment and better mimic conditions in the oral cavity. Also, late-colonizing oral bacteria can be incorporated into the bacterial polyculture to better simulate oral biofilms in vivo. Furthermore, the formation of a protein film known as the salivary pellicle was not used in the present study, which can affect bacterial adherence. Although macrophage proliferation was evaluated in the present study, macrophage polarization to either a pro-inflammatory (M1) or antiinflammatory (M2) response is crucial in assessing the outcome of osseointegration post-implantation. Future work will study macrophage polarization on surface-treated cpTi, Y$\mathrm{ZrO}_{2}$, and $\mathrm{Mg}-\mathrm{ZrO}_{2}$ by staining them with antibodies specific to M1 or M2 macrophage phenotypes. Also, only three surface treatments (polishing, acid-etching, and sandblasting) were 
examined in the present study; assessing other commercial implant surface treatments such as laser modification of Y$\mathrm{ZrO}_{2}$ surfaces and applied coatings with materials like hydroxyapatite or even combinations of them like sandblasting, large-grit and acid-etching (SLA) and modified SLA (modSLA) can provide further insight into surface cues that promote mammalian cell growth and attachment. Finally, both oral bacteria and mammalian cells encounter each other and compete for coverage of implant surfaces in vivo. Future work will develop a co-culture model to assess the competition between oral bacteria and mammalian cells on cpTi, $\mathrm{Y}-\mathrm{ZrO}_{2}$, and $\mathrm{Mg}-\mathrm{ZrO}_{2}$ in vitro.

\section{Conclusion}

In summary, early-colonizing Streptococcus species exhibited a statistically similar degree of bacterial attachment on cpTi, Y$\mathrm{ZrO}_{2}$, and $\mathrm{Mg}-\mathrm{ZrO}_{2}$ after 1 and 3 days of growth in both monoculture and polyculture. However, average adherent bacterial count tended to increase on rougher surface variants (acid-etched or sandblasted) relative to smooth, polished ones. Additionally, macrophages, fibroblasts, and pre-osteoblasts proliferated equally well on both surface-treated cpTi, Y-Z $\mathrm{ZO}_{2}$, and $\mathrm{Mg}-\mathrm{ZrO}_{2}$ surfaces, which all exhibited relatively hydrophilic surfaces. Although cpTi-A initially resulted in significantly higher proliferation of both macrophages and fibroblasts after 1 and 3 days of growth as compared to all other groups, cpTi, Y$\mathrm{ZrO}_{2}$, and $\mathrm{Mg}-\mathrm{ZrO}_{2}$ surfaces were completely covered by fibroblasts and pre-osteoblasts after 7 days. Surface features such as pitting generated after acid-etching influenced both oral bacterial attachment and initial mammalian cell proliferation while rougher cpTi, $\mathrm{Y}-\mathrm{ZrO}_{2}$, and $\mathrm{Mg}-\mathrm{ZrO}_{2}$ surfaces created after acid-etching or sandblasting promoted differentiation of preosteoblasts by 14 days. Within the limitations of the present study, both $\mathrm{Y}-\mathrm{ZrO}_{2}$ and $\mathrm{Mg}-\mathrm{ZrO}_{2}$ are equivalent to cpTi in terms of oral bacterial colonization and mammalian cellular growth. Thus, this systematic study supports the current clinical use of $\mathrm{ZrO}_{2}$ as a suitable alternative to cpTi for dental implant systems based on its biological outcome in vitro.

\section{Conflicts of interest}

There are no conflicts to declare.

\section{Acknowledgements}

The authors acknowledge the International Team for Implantology (ITI), Basel, Switzerland, Grant No. 1175_2016, for providing financial resources to acquire zirconia dental implants and develop the testing methodology used in the present study. This material is also based upon work supported by the National Science Foundation Graduate Research Fellowship under Grant No. 1746053. Any opinion, findings, and conclusions or recommendations expressed in this material are those of the authors(s) and do not necessarily reflect the views of the National Science Foundation. The authors also thank Dr Matthew Di Prima for scanning the specimen surfaces to obtain surface roughness measurements presented in this study.

\section{References}

1 Dental Implants Market to 2027 - Global Analysis and Forecasts by Product; Material; End User and Geography, 2019.

2 J. Holländer, J. Lorenz, S. Stübinger, W. Hölscher, D. Heidemann, S. Ghanaati and R. Sader, Int. J. Oral Maxillofac. Implants, 2016, 31, 855-864.

3 T. Albrektsson and C. Johansson, Eur. Spine J., 2001, 10, S96S101.

4 ADA Council on Scientific Affairs, J. Am. Dent. Assoc., 2003, 134, 347-349.

5 D. R. McEwen, M. M. Sanchez and P. M. Goode, $A O R N$ J., 1995, 62, 187-205.

6 C. Nelson, in Implant Dentistry - A Rapidly Evolving Practice, ed. I. Turkyilmaz, InTech, London, 1st edn, 2011, pp. 319364.

7 M. Niinomi, Mater. Sci. Eng., A, 1998, 243, 231-236.

8 L. Gaviria, J. P. Salcido, T. Guda and J. L. Ong, J. Korean Assoc. Oral Maxillofac. Surg., 2014, 40, 50-60.

9 A. Nouri and C. Wen, in Surface Coating and Modification of Metallic Biomaterials, ed. C. Wen, Elsevier, Amsterdam, 1st edn, 2015, pp. 3-60.

10 Y. M. Zhang, F. Chai, J.-C. Hornez, C. L. Li, Y. M. Zhao, M. Traisnel and H. F. Hildebrand, Biomed. Mater., 2009, 4, 015004.

11 D. C. Rodrigues, P. Valderrama, T. G. Wilson Jr, K. Palmer, A. Thomas, S. Sridhar, A. Adapalli, M. Burbano and C. Wadhwani, Materials, 2013, 6, 5258-5274.

12 R. Bhola, S. M. Bhola, B. Mishra and D. L. Olson, Trends Biomater. Artif. Organs, 2011, 25, 34-46.

13 S. Sridhar, Z. Abidi, T. G. Wilson, P. Valderrama, C. Wadhwani, K. Palmer and D. C. Rodrigues, J. Oral Implantol., 2016, 42, 248-257.

14 F. J. Gil, A. Rodriguez, E. Espinar, J. M. Llamas, E. Padullés and A. Juárez, Int. J. Oral Maxillofac. Implants, 2012, 27, 6468.

15 D. C. Rodrigues, S. Sridhar, I. M. Gindri, D. A. Siddiqui, P. Valderrama, T. G. Wilson, K.-H. Chung and C. Wadhwani, RSC Adv., 2016, 6, 48283-48293.

16 D. Buser, S. F. M. Janner, J.-G. Wittneben, U. Brägger, C. A. Ramseier and G. E. Salvi, Clin. Implant Dent. Relat. Res., 2012, 14, 839-851.

17 F. J. J. van Velzen, R. Ofec, E. A. J. M. Schulten and C. M. ten Bruggenkate, Clin. Oral Implants Res., 2015, 26, 1121-1128.

18 V. Moraschini, L. A. da C. Poubel, V. F. Ferreira and E. dos S. P. Barboza, Int. J. Oral Maxillofac. Surg., 2015, 44, 377-388.

19 Z. Özkurt and E. Kazazoğlu, J. Oral Implantol., 2011, 37, 367376.

20 K. Nakamura, T. Kanno, P. Milleding and U. Ortengren, Int. J. Prosthodont., 2010, 23, 299-309.

21 R. Osman and M. Swain, Materials, 2015, 8, 932-958.

22 A. Apratim, P. Eachempati, K. Krishnappa Salian, V. Singh, S. Chhabra and S. Shah, J. Int. Soc. Prev. Community Dent., 2015, 5, 147. 
23 K. Kvam and S. Karlsson, J. Prosthet. Dent., 2013, 110, 281287.

24 J. Han, J. Zhao and Z. Shen, Adv. Appl. Ceram., 2017, 116, 138-150.

25 C. Sanon, J. Chevalier, T. Douillard, M. Cattani-Lorente, S. S. Scherrer and L. Gremillard, Dent. Mater., 2015, 31, 1525.

26 D. Hashim, N. Cionca, D. S. Courvoisier and A. Mombelli, Clin. Oral Investig., 2016, 20, 1403-1417.

27 N. Kommerein, S. N. Stumpp, M. Müsken, N. Ehlert, A. Winkel, S. Häussler, P. Behrens, F. F. R. Buettner and M. Stiesch, PLoS One, 2017, 12, e0173973.

28 S. B. P. Fúcio, F. G. Carvalho, L. C. Sobrinho, M. A. C. Sinhoreti and R. M. Puppin-Rontani, J. Dent., 2008, 36, 833-839.

29 T. R. Garrett, M. Bhakoo and Z. Zhang, Prog. Nat. Sci., 2008, 18, 1049-1056.

30 F. Yu, O. Addison, S. J. Baker and A. J. Davenport, Int. J. Oral Sci., 2015, 7, 179-186.

31 T. W. Ammann, G. N. Belibasakis and T. Thurnheer, PLoS One, 2013, 8, e83090.

32 A. Scarano, M. Piattelli, S. Caputi, G. A. Favero and A. Piattelli, J. Periodontol., 2004, 75, 292-296.

33 L. Rimondini, L. Cerroni, A. Carrassi and P. Torricelli, Int. J. Oral Maxillofac. Implants, 2002, 17, 793-798.

34 S. Roehling, M. Astasov-Frauenhoffer, I. Hauser-Gerspach, O. Braissant, H. Woelfler, T. Waltimo, H. Kniha and M. Gahlert, J. Periodontol., 2017, 88, 298-307.

35 F. Ismail, M. Eisenburger, S. Grade and M. Stiesch, Dentistry, 2016, 6, 1-5.

36 B. Zhao, H. C. Van Der Mei, G. Subbiahdoss, J. De Vries, M. Rustema-Abbing, R. Kuijer, H. J. Busscher and Y. Ren, Dent. Mater., 2014, 30, 716-727.

37 B.-C. Lee, G.-Y. Jung, D.-J. Kim and J.-S. Han, J. Adv. Prosthodont., 2011, 3, 81-84.

38 R. Krishna Alla, K. Ginjupalli, N. Upadhya, M. Shammas, R. Krishna Ravi and R. Sekhar, Trends Biomater. Artif. Organs, 2011, 25, 112-118.

39 T. Wassmann, S. Kreis, M. Behr and R. Buergers, Int. J. Implant Dent., 2017, 3, 32.

40 E. Jalalian, S. N. Mostofi, E. Shafiee, A. Nourizadeh, R. A. Nargesi and S. Ayremlou, Adv. Biosci. Clin. Med., 2015, 4, 13-20.

41 A. Almaguer-Flores, R. Olivares-Navarrete, M. Wieland, L. A. Ximénez-Fyvie, Z. Schwartz and B. D. Boyan, Clin. Oral Implants Res., 2012, 23, 301-307.

42 J. Kzhyshkowska, A. Gudima, V. Riabov, C. Dollinger, P. Lavalle and N. E. Vrana, J. Leukoc. Biol., 2015, 98, 953-962.

43 N. Marín-Pareja, E. Salvagni, J. Guillem-Marti, C. Aparicio and M.-P. Ginebra, Colloids Surf., B, 2014, 122, 601-610.

44 H. Terheyden, N. P. Lang, S. Bierbaum and B. Stadlinger, Clin. Oral Implants Res., 2012, 23, 1127-1135.

45 Y. Wang, Y. Zhang, A. Sculean, D. D. Bosshardt and R. J. Miron, Clin. Oral Investig., 2019, 23, 3219-3227.

46 B. Zhao, H. C. van der Mei, M. Rustema-Abbing, H. J. Busscher and Y. Ren, Int. J. Oral Sci., 2015, 7, 250-258.
47 F. P. Nothdurft, D. Fontana, S. Ruppenthal, A. May, C. Aktas, Y. Mehraein, P. Lipp and L. Kaestner, Clin. Implant Dent. Relat. Res., 2015, 17, 1237-1249.

48 R. Depprich, M. Ommerborn, H. Zipprich, C. Naujoks, J. Handschel, H.-P. Wiesmann, N. R. Kübler and U. Meyer, Head Face Med., 2008, 4, 29.

49 M. Payer, M. Lorenzoni, N. Jakse, R. Kirmeier, G. Dohr, M. Stopper and C. Pertl, J. Dent. Implantol., 2010, 26, 20-33.

50 W. M. S. Al Qahtani, C. Schille, S. Spintzyk, M. S. A. Al Qahtani, E. Engel, J. Geis-Gerstorfer, F. Rupp and L. Scheideler, Biomed. Eng., 2017, 62, 75-87.

51 A. Zareidoost, M. Yousefpour, B. Ghaseme and A. Amanzadeh, J. Mater. Sci.: Mater. Med., 2012, 23, 1479-1488.

52 R. Gruber, E. Hedbom, D. D. Bosshardt, R. Heuberger and D. Buser, Dent. Mater. J., 2012, 31, 1097-1102.

53 A. Meza-Rodríguez, O. Martínez-Álvarez, L. Acosta-Torres, J. de la Fuente-Hernández and R. García-Contreras, J. Oral Res., 2016, 5, 194-199.

54 A. Pae, H. Lee, H.-S. Kim, Y.-D. Kwon and Y.-H. Woo, Biomed. Mater., 2009, 4, 025005.

55 R. Gapski and E. F. Martinez, Implant Dent., 2017, 26, 373377.

56 M. Gahlert, S. Röhling, M. Wieland, C. M. Sprecher, H. Kniha and S. Milz, Clin. Oral Implants Res., 2009, 20, 1247-1253.

57 N. Cionca, D. Hashim and A. Mombelli, Periodontol. 2000, 2017, 73, 241-258.

58 M. Köunönen, M. Hormia, J. Kivilahti, J. Hautaniemi and I. Thesleff, J. Biomed. Mater. Res., 1992, 26, 1325-1341.

59 D. R. de Carvalho, P. S. P. de Carvalho, O. Magro Filho, J. D. B. de Mello, M. M. Beloti and A. L. Rosa, Braz. Dent. J., 2010, 21, 3-11.

60 H. Kim, S. H. Choi, J. J. Ryu, S. Y. Koh, J. H. Park and I. S. Lee, Biomed. Mater., 2008, 3, 1-6.

61 S.-H. Gong, H. Lee, A. Pae, K. Noh, Y.-M. Shin, J.-H. Lee and Y.-H. Woo, J. Adv. Prosthodont., 2013, 5, 416.

62 R. K. Alla, K. Ginjupalli, N. Upadhya, M. Shammas, R. K. Ravi and R. Sekhar, Trends Biomater. Artif. Organs, 2011, 25, 112118.

63 H. Watanabe, K. Saito, K. Kokubun, H. Sasaki and M. Yoshinari, Dent. Mater. J., 2012, 31, 806-814.

64 K. Webb, W. Li, R. W. Hitchcock, R. M. Smeal, S. D. Gray and P. A. Tresco, Biomaterials, 2003, 24, 4681-4690.

65 S.-M. Bang, H.-J. Moon, Y.-D. Kwon, J.-Y. Yoo, A. Pae and I. K. Kwon, Clin. Oral Implants Res., 2014, 25, 831-837.

66 J. Wu and Z. Peng, J. Biomed. Mater. Res., Part B, 2015, 103, 751-763.

67 A. Wennerberg, S. Galli and T. Albrektsson, Clin., Cosmet. Invest. Dent., 2011, 3, 59-67.

68 E. Mariscal-Muñoz, C. A. S. Costa, H. S. Tavares, J. Bianchi, J. Hebling, J. P. B. Machado, U. H. Lerner and P. P. C. Souza, Clin. Oral Investig., 2016, 20, 503-511.

69 C. Yin, Y. Zhang, Q. Cai, B. Li, H. Yang, H. Wang, H. Qi, Y. Zhou and W. Meng, J. Biomed. Mater. Res., Part A, 2017, 105, 757-769.

70 U. Hempel, T. Hefti, M. Kalbacova, C. Wolf-Brandstetter, P. Dieter and F. Schlottig, Clin. Oral Implants Res., 2010, 21, 174-181. 